\title{
Historia blog \\ The OVER THE ORANGE TIMES, World War One Imaginary: An explanation
}

\section{Bill Nasson*}

Are centenaries surely not the best times imaginable for fabrication, invention or otherwise making it up? Conventionally, it is nationalists who refract the history of their countries through heroic narratives - including tall stories - of one kind or another. Indeed, those sacrificial narratives of trial and tribulation have come to be anointed as the agent of history itself. While the pugnacious sentimentalism of South Africa's woeful nationalists, past and present, has produced some first-class national fictions, one ought not to overlook impressive competition from various other places with a colonial past.

Take the Irish, for instance. It is not for nothing that the sub-title of R.F. Foster's acerbic 2001 examination of the therapeutic agony tourism of Famine themeparks (and much else besides) in The Irish Story, is Telling Tales and Making it Up. It is, at times, impossible not to wonder who this sort of massage-parlour history is for, with its "conversation interfaces" and "interpretation centres" - where the grammar and the interpreting are, of course, provided for you in advance by the licensed custodians of historical memory. In current South Africa, compensatory history or history as therapy seems to have become all the rage, as a sanitising vanguard of energetic late-adolescents undertake the erasing of this historical artwork or that historical statue, evidently in pursuit of bringing about a therapeutic catharsis. By turning historical consciousness into a laundry list of individual psychological issues to be got through - trauma, pain, guilt, complicity, silencing, liberating, reclaiming communal memory can become a more comforting kind of psychic refuge. As Roy Foster has observed, memorably, the replacement of unwelcome history by psychotherapy involves historical time-travelling on an ambitious scale, be it the British Crown apologising to the Maoris, or the Pope apologising in 1992 for the Vatican's persecution of Galileo in 1633. Or, for that matter, the University of Cape Town's recent dutiful removal of the statue of Cecil John Rhodes.

Along with all this activity around history as therapy, it is worth remembering a distinctive time of therapy in history, when it was an acutely felt need in human

* Bill Nasson is a professor of History at the University of Stellenbosch. His History
Matters: Selected Writings 1970-2016 will be published by Penguin later this year.

How to cite this article:

B. Nasson, "Historia Blog. The OVER THE ORANGE TIMES, World War One Imaginary: An explanation", Historia 61, 1, May/Mei 2016, pp 155-162.

http://dx.doi.org/10.17159/2309-8392/2016/v61n1a11

Copyright: (CThe Author(s). Published under a Creative Commons Attribution Licence. 
experience. We are living through the centenary of the Great War, that harrowing bloodbath which tested the limits of human endurance on its most vicious fighting fronts. For some deeply traumatised soldiers, officially-authorised therapy to help them to keep going was, so to speak, a deadly serious business. Many victims of shellshock were subjected to primitive electro-convulsive shock treatment, while a few others, like the hospitalised British officers in Pat Barker's brilliant Regeneration Trilogy (1991-95) series of historical novels, were fed "the talking cure" of preFreudian psychoanalysis. French infantry categorised as "mentally unsound" were withdrawn to Paris, where they were taught the soothing domestic routines of female handicrafts such as knitting, sewing and weaving. Once they had learned to overcome shaking spasms and trembling and had become steady enough to hold and fire a rifle once again, they were returned to the front. In a way, men who had lost their martial masculinity had to immerse themselves in a female space to restore their warrior capability.

At the same time, ordinary soldiers themselves devised their own rough mental blankets as some insulation against the worst which 1914-18 was throwing at them. It was humour of a type reflected here by a small historical invention, the Over the Orange Times. A South African wartime fable, it is a pastiche of limericks, reworked nursery rhymes, doggerel verse, newspaper letters and sketches, mimicking the celebrated The Wipers Times. What was The Wipers Times? That was a sardonic magazine of trench life, written, drawn and read by British army soldiers on the Western Front. Circulating from 1916 to 1918, The Wipers Times was printed on an abandoned press salvaged from the smoking ruins of the Belgian town of Ypres hence its hilarious title, mocking the common English mispronunciation. Assuming a South African content, you can almost hear some Bloemfontein sergeant asking for De Eeepse Koerant.

For British officers, the parade assembly bark, "are we as offensive as we might be?" was intended to fire up frontline infantry to go over the top and charge at the Germans. But as a motto for cheeky contributors to The Wipers Times, it came to mean something quite different, inspiring sarcasm, black humour, and a sly, levelling malice. If the cataclysm of the Great War proved more than ever before that "war is hell", as the American Civil War general, William Sherman, concluded so memorably in 1879 , for some in it there was the scurrilous refuge of mockery, tastelessness and absurdity. That served as a psychic crutch in helping, perhaps, to make that hell just a little bit more endurable.

In one obvious way, war satire produced by ordinary soldiers themselves can be seen as giving the finger to the official propaganda sheets aimed at them by their governments. Thus, in the French Army from 1914, frontline infantrymen commonly described their official war bulletins as le petit menteur (the little liar), preferring the vividness, vulgarity and overripe sentiment of their own entertainingly scurrilous trench sheets. Similarly, readers who are acquainted with the concluding First World War episodes of the acclaimed 1989 BBC Television series, Blackadder, will remember Captain Edmund Blackadder's scorn at Lieutenant George's excitement 
over King and Country, a propaganda magazine which he dismisses as fit only for use as second-grade toilet paper.

Equally, at another level, so cynical a pose could also be viewed as a resilient expression of the human spirit, a dogged determination to keep at bay the worst that the war was inflicting on its combatants. In that sense, the distraction of nonsensical or satirical humour formed a therapeutic defence, a mental shelter from the war's brutalities, obscenities and pitilessness. For men in extreme circumstances, flashes of black humour were one of the tools for surviving and functioning, a respite from the shock of battlefields which Germany's Crown Prince Wilhelm likened to a mill which "ground up the hearts of the soldiers as much as their bodies". Shared reading and shared laughter played their part, alongside the recreational distractions of rugby, football, cricket, swimming, athletics and even dominoes which are credited more commonly as activities which helped to make the war bearable.

While it may not have been conventionally patriotic, what became known as 'trench journalism' helped, in its way, to sustain soldiering morale, if hardly in the inspiring manner envisaged by ruling politicians. Its merit was that it was rough, with rough journals varying in their roughness. While The Wipers Times came from a press, others were produced as crude, hand-lettered and sketched products, disseminated as carbon copies. In cultural taste, too, they would have differed in tone and style. The archetypal foot-slogging urban British Tommy was not the archetypal foot-slogging rustic French poilu (literally, "hairy one"), even less the archetypal colonial French West African infantryman or Tirailleur Senegalais.

Moreover, the circulating presence of popular sheets in the ranks also sowed the seeds of - or watered already established - national and other distinct soldiering identities. Thus, The Iodine Chronicle of the Canadian Expeditionary Force in Europe came, unsurprisingly, from a Field Ambulance Company. In bristling assertions of a self-reliant and pugnacious "national character", there was no mistaking which Army Corps was associated with Aussie and Digger. At the same time, what linked these all together was a shared irreverence towards army authority, respectfulness, morality and other pieties and politeness. For, ultimately, what counted for the "trench journalist" was not the colour of the uniform but the ruefulness and eccentricity of their sentiment. At the most general level, what flitted across their carbon-copies was a universal sang-froid in which "rest camps" invariably meant cemeteries.

What of South African impulses from this worm's-eye gaze? So far as can be ascertained, Union forces, whether on their African campaign fronts or in Europe, did not create organised "frontline" journalism of the type associated with British armies on the Western Front and some of the other Dominion expeditionary forces. Why not? In part at least, perhaps because they lacked the sustaining requisites of a large mass of infantryman who all shared the same single language.

Nonetheless, their position as an imperial fighting corps within a British body could not but have led to some exposure to, and some assimilation of, the ironic world 
of The Wipers Times. For it was, undoubtedly, contagious. As one of the then last surviving South African veterans of the Somme Battle of Delville Wood recalled in an interview in 1997, once his platoon sergeant returned with "a few really chewed-up copies of those trench paper funnies the English boys were coming out with". Their contents were "simply mad, just ludicrous ... but what a tonic back then, man, it was almost like getting a nice plate of fresh fried eggs". Private Joe Samuels and his mates felt that it was "a little like seeing a paper, only just mainly full of cartoons and other stupid stuff about being where we were". In that way, for all that it was steeped in the matter of the war, a trench journal could still bring to the front a welcome trace of ordinary civilian habits and inclinations. To which can be added the odd South African sliver. According to Private Samuels, there were snatches of "our Springbok stuff" that did the rounds in his infantry brigade, "a few jokes and sport drawings" on "old cigarette packets or used envelopes, or bits of writing paper". But this never finished up as a jokey publishing enterprise.

Still, when it came to the cultivation of anti-heroics, scattered South African voices were part of the swollen wartime tide of insolence and syrupy emotion. Joe Samuels, again, remembered that while cartoonists of the patriotic press portrayed Botha as a soaring eagle above German South West Africa, some of his more impudent men scribbled him as a fat duck or even a dodo. At home, meanwhile, The Rand Daily Mail, The Natal Mercury and The Potchefstroom Herald heaped praise on the over fifty parodies published personally by Private Sam Naishtad of the $1^{\text {st }}$ SA Infantry. Some breezy, others cloyingly mournful, his 1917 The Great War Parodies: East, Central African and Flanders Campaigns of Well-Known Songs, sold thousands of copies in aid of the South African Prisoners of War Fund. As in "Blind and Crippled", the language of most of these parodies was overwhelmingly British or British Dominion in idiom. Directed to tug at the heart-strings, Naishtad's doggerel verse implored readers to dip into their pockets for disabled brave patriots:

\footnotetext{
They left dependent to depend on them,

To go and crush the German shame;

But now they're back from the land of foe,

Blind and crippled with nowhere to go,

The Kaiser is the man who broke the law,

With greedy hands for all he saw,

He ruined millions of human beings,

With no regard for their feelings.
}

In the Over the Orange Times, we give the wheel a slight turn by inventing a South African strain to the wry mood of trench journalism. In fact, in the Union something of that flavour was expressed at times in publication, but, interestingly, after the war. Veterans' publications of the 1920s, such as The Home Front and The Springbok Blue featured peevish male stories about the stock assumptions of females. One, in the November 1928 issue of The Home Front featured the fancy Durban "womenfolk", standing in packed tramcars. They were put out by the "ill manners" of "some of the men", who failed ungraciously to offer them their seats. "Bit thick", sneered one irritated veteran, expected to "ave to stand up on half a leg", his 
treasured souvenir of "the great crime of 1914-1918". Here, then, had it existed, is how the Over the Orange Times might have been. Historically, it may be a phoney. But it is a real phoney.

\section{The OVER THE ORANGE TIMES, December 1917}

(Our motto: We stand by or above our comrades - alive and dead)

\section{People we take our hats off to}

- The English ornithologist in search of the red-white-and-blue feathered fish eagle of the Western Transvaal.

- The King's favourite colonial equerry who also appears in khaki disguise as our gallant Minister of Defence, industrious Minister of Mines, Climber of Kilimanjaro and now chief map-spreader of the Imperial War Cabinet. Will nothing stop him?

- General Louis Botha who went, who saw, and who conquered for us to feel grand. True, it may not be another Rand. But it is most certainly a lot of sand.

- The truly loyal burghers of Bloemfontein, still out salting biltong for Belgium.

- Dr Abdurahman, a right Royal Cape patriot, blowing hot never cold. Khaki bids for his pin-stripe suit have yet to open.

- The Expert Diggers from the Kimberley Club, tirelessly doing their bit to keep the fields downwind of Paris free of too much foreign clutter.

- The sheep of the Karoo whose wool, we hear, is fetching a handsome price. Truly, those sheep are not slackers.

\section{Insects we take our hats off to}

- The mozzies of German East Africa for giving the nurses of Natal something to do.

- Those scheming flies around Tsavo and Ruaha for teaching the horses to eat less and nap more. We strongly advise Basuto ponies to stay in Basutoland.

- For almost getting the Mounted Rifle boys to cry, "oh, for Umtata" - those accursed Egyptian fleas. 


\section{Letters to the Editor}

To the Editor, The Mombasa \& Port Shepstone Clarion

Sir,

I do not agree with your Calcutta correspondent, Havildar Singh, who advises that South African infantrymen should really learn to ride on elephants instead of running away from them. I suggest that it would require training first in tiger-hunting. In current local circumstances, this would be less taxing than German-hunting. The only pity is that out there we are somewhat short of tigers. On the other hand, I commend with gusto the proposal that the less chesty boys of the Durban Light Infantry be awarded a Star - possibly, even a Star and Klipspringer - for offering to do press-ups in public with the athletic General Van Deventer.

I am, Sir,

Yours obediently, etc.,

An Old Rand Contemptible (Barberton Distillery Rear Division)

\section{This week - AND FOR ONE WEEK ONLY!}

A thrilling series of highly educational lectures will take place in the forward pigeon chamber of the Rand Club.

Dress: Black Tie Mills bomb. Lewis gun optional.

The following luminaries have generously undertaken to speak:

- Sir FLANNEL SHAFT - Subject: "What shall we do with the Bank of England?"

- Mr JACOBUS VAN VRUGTE - Subject: "The blessings of apricots, peaches, pineapples and tin cans".

- Viscount SPANKER - Subject: "The servant problem in the Union despite German South West: improving deportment for Zulu butlers".

- Brigadier EDWARD NOTT-SOLIGHTLEE - Subject: "Recent Native and Boer restiveness and continuing troubled times to our north: the need for remaining vigilant".

- Madam ETHEL WELLBELOVED - Subject: "War relief and spiritual upliftment for the common man through musical chairs".

- Major M.T. SHELVES - Subject: "The Jaeger flea-bag and its many varied uses: under fire and near the fire".

- Captain CLAUDE TRUDGE-MUDD - Subject: "Daily life along the Ypres duckboards: ducking with dexterity". 
- Lieutenant-Colonel C. BARE BLANCMANGE - Subject: "Interesting waterfalls and flora encountered on a Kalahari crossing".

NO SEATS RESERVED! As there is certain to be a great demand for places, those who wish to hear these Lectures are urged to arrive at dawn.

Delectable canapés will be served, including chlorine biltong, mustard melktert and saltpetre-matured vetkoek.

Daily Times: Zero, 7.30pm. SOS, 7.45pm. Stretchers, 8pm. Caskets, 8.15pm.

\section{Our Monthly Poetry Selection Winners}

\section{Almost over by Xmas}

Sing a song of rebellion

Pockets full of hope

Four and twenty Boers with beards

Fancying they'd slip the rope

As those beards were singed

Lord Harcourt cried, 'O my!'

That Union can't be orange-tinged

When upon it we rely.

\section{The Sands of Success}

There was a General called Botha

Who conquered South West in a motor

While far from the Rand

He got stuck in the sand

Yet nobody took a photo.

\section{Beating about the Bush}

A most healthy general is Smuts or Jannie Never easy for boys who are queasy

Nor very famous for being funny

What with old England's call

To catch the Kaiser's Askari

Rather than just fair Sarie

They hit the deck before getting it in the neck

So for slim Jannie

It's London which is more sunny.

\section{Grand Sale of Choice Items (all reasonable offers considered)}

- Authentic Delville Wood tree leaf (slightly shredded) - a genuine rarity.

- Transvaal Scottish gas mask. One previous owner. Minor perforations. Approved by the Flanders Hydrochlorine Commission.

- Two dozen portable stinkhout crosses. Treated to resist maggots. 
- One large personal truss. Endorsed by General Botha. Carrying capacity: one large carcass (wildebeest) and one medium corpse (Rand Rifleman).

- Diamond-encrusted bandolier. Rare unmarked condition. Only limited service on the Knightsbridge Front with the Sir Ernest Oppenheimer Amsterdam Appraisal Corps.

And so on, and so forth .... 